\title{
Bir Eğitim Araştırma Hastanesinde Yatan Çocuk ve Ergen Hastalar için İstenilen Psikiyatrik Konsültasyonların Değerlendirilmesi
}

\author{
Evaluation of Psychiatric Consultations Requested for Child and \\ Adolescent Patients Hospitalized in a Training and Research \\ Hospital
}

Ayşe Nihal ERASLAN¹, Rezzan AYDIN GÖRÜCÜ¹, Arzu YILMAZ²

'SBÜ, Ankara Eğitim ve Araştırma Hastanesi, Çocuk ve Ergen Ruh Sağlığı ve Hastalıkları Bölümü, Ankara, Türkiye

²SBÜ, Ankara Eğitim ve Araștırma Hastanesi, Çocuk Nöroloji Bölümü, Ankara, Türkiye

\section{ÖZ}

Amaç: Hastanede yatan çocuk ve ergenlerdeki psikiyatrik semptomların tanınması, zamanında müdahale ve tedavi edilmesi oldukça önemlidir. Bu çalışmada bir eğitim araştırma hastanesindeki çocuk ve ergen psikiyatrisi konsültasyonlarının özelliklerinin incelenmesi amaçlanmıştır.

Gereç ve Yöntemler: Mayıs 2016-Ekim 2018 tarihleri arasında yatan hasta kaydı bulunan çocuk ve ergen hastalar için istenen çocuk psikiyatri konsültasyonları geriye dönük olarak incelendi. Demografik ve klinik özellikler SPSS (Sosyal Bilimler İçin İstatistik Paket Programı) 17.0 kullanılarak analiz edildi. Sürekli değişkenlerin normal dağılıma uygunluğu Kolmogorov-Simirnov ile test edildi, karşılaştırmalarında Mann Whitney U testi kullanıldı. Kategorik değişkenler sıklık (n) ve yüzde (\%) cinsinden ifade edildi ve Pearson ki-kare testi ile karşılaştııldı. $p<0.05$ anlamlılık düzeyi olarak kabul edildi.

Bulgular: Araştırma kapsamında değerlendirilen toplam 127 çocuk ve ergenin \%66.9'u (n=85) kızdı. Olguların \%78.7'sini ergen (13-17) yaş grubu oluşturuyordu. Psikiyatrik değerlendirmenin istenildiği klinikler içinde, en büyük oranda istemin \%93.7 ( $n=119$ ) ile pediatri bölümünden yapıldığı tespit edildi.

Olgulardan konsültasyon istenme nedenleri değerlendirildiğinde en sık intihar girişimi nedeniyle konsültasyon istendiği saptandı (\%55.1, n=70). Değerlendirilen kesitte, olguların \%19.7' sinde ( $n=25)$ en az bir psikiyatrik bozukluk saptandı. Olguların \%18.1'ine en az bir psikotrop ilaç önerildiği bulundu.

Sonuç: Çalışmamızda Konsültasyon Liyezon Psikiyatrisi biriminin önemine dikkat çekilmiştir. Konsültasyon-Liyezon alanındaki farkındalığın artması olumlu yönde bir gelişme olarak değerlendirilmiş ancak bu alandaki hizmetlerin daha fazla geliştirilmesi gerektiği düşünülmüştür. Ülkemizde yapılan çalışmalarda bulunan farklı sonuçlar değerlendirildiğinde konsültasyon-liyezon alanında ortak bir dil ve algoritma oluşturulmasının önemli olduğu düşünülmüştür.

Anahtar Sözcükler: Çocuk, Ergen, Konsültasyon, Psikiyatri

(1)

ERASLAN AN AYDIN GÖRÜCÜ R YILMAZA
:0000-0002-7655-7927 $0000-0002-8721-4073$ 0000-0003-2550-9324
Çıkar Çatışması / Conflict of Interest: Tüm yazarlar adına, sorumlu yazar çıkar çatışması olmadığını belirtir.

Etik Kurul Onayı / Ethics Committee Approval: Bu çalıșmada ulusal ve uluslararası etik kurallara uyulmuștur. Çalıșma için; T.C.S.B Sağlık Bilimleri Üniversitesi Ankara Sağlık Araștırma Uygulama Merkezi Tıpta Uzmanlık Eğitim Kurulu 14.11.2018-60 tarih-numaralı toplantısında 620 numaralı karar ile onay alınmıştır.

Yazarların katkısı / Contribution of the Authors: ERASLAN AN: Araștırma ve/veya makalenin hipotezini veya fikrini olușturan, Sonuçlara ulașmak için planlama/metodoloji belirleme, Araştırma/çalışmanın sorumluluğunu üstlenmek, ilerlemenin seyrini denetlemek, Hasta takibinde sorumluluk almak, ilgil biyolojik malzemelerin toplanması, veri yönetimi ve raporlama, deneylerin yürütülmesi, Sonuçların mantıksal olarak Yorumlanması ve sonuçlandırılması, Calısma için gerekli literatür taramasında sorumluluk almak, Çalıșanın bütününün veya önemli bölümlerinin yazımında sorumluluk almak, Yazım ve dilbilgisi dıșnda bilimsel olarak gönderilmeden önce makaleyi gözden geçirme. AYDIN GÖRÜCÜ R: Araștırma/çalıșmanın sorumluluğunu üstlenmek, ilerlemenin seyrini denetlemek, Hasta takibinde sorumluluk almak, ilgili biyolojik malzemelerin toplanması, veri yönetimi ve raporlama, deneylerin ilerlemenin seyrini denetlemek, Hasta takibinde sorumluluk almak, ilgili biyolojik malzemelerin toplanması, veri yönetimi ve raporlama, deneylerin
yürütülmesi, Sonuçların mantıksal olarak Yorumlanması ve sonuçlandırılması, Çalıșma için gerekli literatür taramasında sorumluluk almak, Çallșmanın yürütülmesi, Sonuçların mantı̈n veya önemli bölümlerinin yazımında sorumluluk almak, Yazım ve dilbilgisi dıșında bilimsel olarak gönderilmeden önce makaleyi gözden geçirme. YILMAZ A: Araștırma ve/veya makalenin hipotezini veya fikrini olușturan, Sonuçlara ulașmak için planlama/metodoloji belirleme, Araștırma/ çalıșmanın sorumluluğunu üstlenmek, ilerlemenin seyrini denetlemek, Hasta takibinde sorumluluk almak, ilgili biyolojik malzemelerin toplanması, veri yönetimi ve raporlama, deneylerin yürütülmesi, Sonucların mantıksal olarak Yorumlanması ve sonuclandirıması, Calısma için gerekli literatür taramasında sorumluluk almak, Çalıșmanın bütunununun veya onemli bolümlerinin yazımında sorumluluk almak, Yazım ve dilibilgisi dişsında bilimsel olarak gönderilmeden
önce makaleyi gözden geçirme.

Atıf yazım şekli / How to cite : Eraslan AN, Aydın Görücü R, Yılmaz A. Bir Eğitim Araştırma Hastanesinde Yatan Çocuk ve Ergen Hastalar için İstenilen Psikiyatrik Konsültasyonların Değerlendirilmesi. Türkiye Çocuk Hast Derg 2021;15:451-458.
Yazışma Adresi / Correspondence Address:

Ayşe Nihal ERASLAN

SBÜ, Ankara Eğitim ve Araştırma Hastanesi,

Çocuk ve Ergen Ruh Sağlığı ve Hastalıkları Bölümü, Ankara, Türkiye

E-posta: aysenihaleraslan@gmail.com
Geliş tarihi / Received : 10.08.2020 Kabul tarihi / Accepted : 06.10.2020 Elektronik yayın tarihi $\quad$ : 27.01.2021 Online published

DOI: 10.12956/tchd.778921 


\section{ABSTRACT}

Objective: In hospitalized children and adolescents recognition of psychiatric symptoms, timely intervention and treatment are quite important. In this study, it was aimed to examine the characteristics of child and adolescent psychiatry consultations in a training and research hospital.

Material and Methods: The psychiatric consultations of the child and adolescent inpatients between May 2016- October 2018 were assessed retrospectively. Demographic and clinical characteristics were analyzed using SPSS (Statistical Package Program for Social Sciences) 17.0. The compliance of continuous variables to normal distribution was tested using Kolmogorov-Simirnov test, Mann Whitney $U$ test was used for comparisons. Categorical variables were expressed in terms of frequency (n) and percentage (\%) and compared using the Pearson chi-square test. $p$ values $<0.05$ were regarded as statistically significant.

Results: $66.9 \%$ ( $n=85$ ) of 127 children and adolescents evaluated within the scope of the study were females. $78.7 \%$ of the cases were in adolescent age group (13-17). Among the clinics that requested psychiatric evaluation, it was found that the highest rate of consultation was requested from the pediatric department with $93.7 \%(n=119)$. Considering the reasons for requesting a consultation from the cases, it was found that the most requested consultation reason was the evaluation of suicide attempts $(55.1 \%, n=70)$. In the cross section evaluated, $19.7 \%(n=25)$ of the cases were found to have at least one psychiatric disorder. It was found that at least one psychotropic drug was recommended to $18.1 \%$ of the cases.

Conclusion: The importance of the Consultation-Liaison Psychiatry unit was highlighted in our study. Increasing awareness in the field of Consultation-Liaison is considered as a positive development, but it is thought that the services in this area should be improved more. Considering the different results found in the studies conducted in our country, to create a common language and algorithm in the field of consultation-liaison is thought to be important.

Key Words: Child, Adolescent, Consultation, Psychiatry

\section{GiRiş}

Konsültasyon liyezon psikiyatrisi (KLP), biyo-psiko-sosyal modeli temel alan, hastanın değerlendirilmesinde biyolojik, psikolojik, çevresel ve sosyokültürel etkenlerin de dikkate alınması gerektiğini vurgulayan, tıp ile psikiyatriyi bütünleştiren bir disiplindir (1,2). Bu disiplinin amacı diğer tıbbi bölümlerdeki psikiyatrik durumları tanımak, tedavi etmek, hastalığın başında ya da sürecinde ortaya çıkan psikososyal etmenler gibi faktörleri inceleyerek tıbbi değerlendirmenin bütüncül olmasını sağlamaktır. Hastalıkların biyolojik olduğu kadar psikolojik ve sosyal yanları da vardır (3). Fiziksel hastalığı olan bireylerde psikiyatrik hastalık görülme olasilığının sağlıklı bireylere göre daha yüksek olduğu ve bu oranın \%40' lara kadar çıkabildiği bildirilmişsir $(3,4)$. Fiziksel hastalığı olanlarda eşlik eden psikiyatrik bozukluk sıklıkları çeşitli araştırmalarda değişebilmektedir (4). Psikiyatrik durumlar, kronik fiziksel hastalıkların ikincil etkileri (depresyon gibi) ile oluşabileceği gibi altta yatan fiziksel bir hastalığın semptomu ya da hastane yatış süreci ile ilgili olarak da ortaya çıkabilir (5). Psikiyatrik desteğin zamanında ve etkili bir şekilde uygulanabilmesini KLP hizmetleri sağlamaktadır (4).

Konu ile ilgili yapılan araştırmalar incelendiğinde, Kılıç ve ark. tarafindan yapılan bir çalışmada yetişkin psikiyatri bölümüne konsülte edilen yatan hastaların \%76.2' sinde psikiyatrik bir bozukluk saptanmıștır (5). Pezzia ve ark.(6) tarafindan yatan hastalarla yapılan bir çalışmada psikiyatri konsültasyon oranı \%7.5 olarak bulunmuşken, Chen ve ark. (7) tarafından yapılan derleme çalışmasında bu oranın \%0.72-\%5.8 arasında olduğu belirtilmiştir. Fiziksel ve ruhsal hastallk birlikteliği, işlevselliğin daha çok bozulmasına, hastane yatış süresinin uzamasına ve hastaneye yatış oranlarının artmasına neden olmaktadır $(3,4)$. Psikiyatri dışı tıbbi hastalıklar nedeniyle hastanede yatan hastalarda eşlik eden psikiyatrik bozukluklara yeterince değinilmemekte ve psikiyatrik tanı-tedavi süreci gecikebilmektedir (5). KLP' nin önemli işlevlerinden biri de hekimlerin psikiyatrik bozukluklara karşı farkındalı̆̆ını artırmak ve psikiyatrik semptomları doğru tanımasını sağlamaktır (4).

Herhangi bir nedenle hastanede yatıyor olmanın çocukları birçok yönden etkileyebildiği ve çocukların kaygılarını artırabildiği belirtilmiştir. Hastaneye yatan çocukların \%20-35'inde hastalıktan bağımsız olarak psikolojik stres bildirilmiştir (3). Yapılan bir çalışmada pediatri servisine kabul edilen fonksiyonel somatik semptomları olan çocukların \%40'ında taburculuk tanılarının birincil olarak psikiyatrik tanı olduğu saptanmıştır (8). Kronik hastalığı olan çocuklarda sağlıklı akranlarına göre daha fazla duygusal ve davranışsal sorunlar bildirilmiștir (9). $\mathrm{Bu}$ çalışmalar, KLP hizmetlerinin sadece erişkinlerde değil çocuklarda da oldukça önemli olduğunu göstermektedir.

Çocuklar için istenen psikiyatri konsültasyonları çeşitli nedenlerle olabilir (10). Konsültasyonların çoğu sağlık çalışanının bir sorun görmesi üzerine istenmekte ancak bazen hastanın kendisinin isteği olabilmektedir (11). Çocuk ve ergen psikiyatrisi ile yetişkin psikiyatrisi bölümlerinden istenilen konsültasyon sebeplerinin çoğunluğu benzerlik göstermektedir; ancak bazı durumlar çocuk popülasyonuna özgü olup çocuklara özel gelişimsel yaklaşım gerektirmektedir (10). Tüm bunlar değerlendirildiğinde fiziksel hastalığı olan çocuklardaki psikiyatrik semptomların tanınması, zamanında müdahale edilmesi ve tedavi edilmesinin oldukça önemli olduğu söylenebilir. Konsültasyon-liyezon alanının geliştirilebilmesi ve bu alanda verilen hizmetlerdeki eksikliklerin saptanabilmesi için bu konuda yapılan çalışmalar önemlidir. Bu zamana kadar ülkemizde yapılan çalıșmalar KLP' nin önemini vurgulamakla birlikte çalışmalarda bulunan farklı sonuçlar daha çok araştırmaya intiyaç olduğunu düşündürmektedir.

Çalışmamızın amacı bir eğitim araştırma hastanesinde yatan hastalardan istenen çocuk ve ergen psikiyatrisi 
konsültasyonlarının özelliklerini incelemek böylelikle bir durum saptaması yapmak, bulunan sonuçları bu konuda yurtiçinde ve yurtdışında yapılan çalışmalarla karşılaştırarak KLP hizmetlerinin mevcut durumunu tartışmak ve ileride yapılacak çalışmalara yol gösterebilmektir.

\section{GEREÇ VE YÖNTEMLER}

Mayıs 2016-Ekim 2018 tarihleri arasında Ankara Eğitim ve Araştırma Hastanesi' nde yatan hasta olarak kaydı bulunan ve Çocuk Psikiyatrisi Bölümü' ne konsülte edilmiş tüm çocuk ve ergen olgular araştırma kapsamında değerlendirildi. Araştırmanın dışında tutulan olgu bulunmamaktadır. Çocuk psikiyatri konsültasyon hizmetleri hastanemizde aktif olarak çalışan tüm çocuk psikiyatri uzmanları tarafından sıra ile rotasyon şeklinde verilmekte olup belirli zaman aralıklarında sorumlu bir uzman konsültan hekim bulunmaktadır. Çalışma için olguların elektronik hastane dosyaları geriye dönük incelendi. Çalışma kapsamında konsültasyon istenen olguların sosyodemografik özellikleri, hastanede yatış nedenleri, çocuk psikiyatri konsültasyonu istenme nedenleri, konsültasyon sonucunda saptanan psikiyatrik tanıları, önerilen ilaç tedavileri ve konsültasyonun hangi bölüm tarafından istendiği değerlendirildi. Yaş grupları 2-12 yaş arası "çocuk", 13-17 yaş arası "ergen" grubu olarak kabul edildi. Konsültasyon isteyen bölümün adı hastane elektronik sisteminde geçen ad ile kodlandı. Hastanede yatış nedeni için fiziksel tıbbi hastalık ayrıntısına girilmemiş olup gruplandırma daha genel ifadeler ile yapıldı. Konsültasyon istenme nedeni konsültasyon istem notuna ya da psikiyatri cevap notuna bakılarak saptandı. Aktif psikiyatrik bir yakınma ya da semptom olmadan sadece kronik fiziksel bir hastaliğın olması nedeni ile tarama amaçlı istenen konsültasyonlar "Kronik hastalık varlığı" olarak gruplandırıld. Psikiyatrik tanılar, klinik görüşme ve değerlendirme sonucunda DSM-5 (Mental Bozuklukların Tanısal ve Sayımsal El Kitabı, The Diagnostic and Statistical Manual of Mental Disorders) tanı sınıflamasına göre konuldu.

Çalışma için; T.C.S.B Sağlık Bilimleri Üniversitesi Ankara Sağlık Araştırma Uygulama Merkezi Tıpta Uzmanlık Eğitim Kurulu 14.11.2018-60 tarih-numaralı toplantısında 620 numaralı karar ile onay alınmıştır.

\section{İstatistiksel Analiz}

Analizler SPSS (Sosyal Bilimler İcin İstatistik Paket Programı) versiyon 17.0 (Chicago Inc., 2008) programı ile yapıldı. Sürekli değişkenler ortanca, minimum ve maksimum değerler cinsinden ifade edildi. Sürekli değişkenlerin normal dağılıma uygunluğu Kolmogorov-Simirnov ile test edilerek, karşılaştırmalarında Mann Whitney U testi kullanıldı. Kategorik değişkenler sıklık (n) ve yüzde (\%) cinsinden ifade edildi ve Pearson ki-kare testi ile karşılaştııılı. p<0.05 anlamlıık düzeyi olarak kabul edildi.

\section{BULGULAR}

Mayıs 2016-Ekim 2018 tarihleri arasında yatan hasta kaydı bulunan 127 çocuk ve ergenden psikiyatrik değerlendirme istenildiği saptandı. Tüm olguların verileri araştırma kapsamında değerlendirildi. Olguların yaş ortanca düzeyi 16 yıl olup minimum 2 yaş, maksimum 17 yaş aralığındaydı. Ergen (13-17) yaş grubu olguların \%78.7'sini, çocuk (2-12 yaş) yaş grubu olguların \%21.3'ünü ( $n=27)$ oluşturuyordu. Olguların \%66.9'u ( $n=85)$ kIz, \%33.1'i $(n=42)$ erkekti. Kız olguların erkek olgulara oranı 2 olarak saptandı. Psikiyatrik değerlendirmenin istenildiği klinikler içinde, en büyük oranda istemin \%93.7 ( $n=119)$ ile pediatri (çocuk sağlığı ve hastalıkları) bölümünden yapıldığı tespit edildi. Konsültasyon istemlerinin kliniklere göre dağlımı ve olguların hastanede yatış nedenleri Tablo l' de gösterildi.

Olgulardan konsültasyon istenme nedenleri değerlendirildiğinde en sık intihar girişimi nedeniyle (\%55.1, $\mathrm{n}=70$ ) konsültasyon istendiği saptandı. Bunu \%15.7 ( $\mathrm{n}=20)$ ile duygusal ya da davranışsal sorunlar (diş gıcırdatma, ajitasyon, hiperaktivite, içe kapanıklık vb) sergileyen çocuk ve ergenlerin değerlendirimesi istemi, \%7.1 ( $n=9)$ ile altta yatan organik bir bozukluğu saptanamayan çocuk ve ergenlerin değerlendirilmesi istemi takip ediyordu. Değerlendirilen kesitte, olguların \%19.7' sinde $(n=25)$ DSM-5 tanı ölçütlerini karşılayan en az bir psikiyatrik bozukluk saptandı. En sık konulan psikiyatrik tanıların \%7.9 $(n=10)$ ile depresyon ve \%3.1 ( $n=4)$ ile anksiyete bozukluğu olduğu görüldü. Olguların konsültasyon istenme nedenlerinin cinsiyetlere göre karşılaştırması Tablo II' de gösterildi.

Olgulardan konsültasyon istenme nedenleri yaş gruplarına göre karşılaştırıldığında, intihar girișimi nedeniyle psikiyatriye

Tablo I: Konsültasyon istemlerinin kliniklere göre dağllımı ve olguların hastanede yatış nedenleri.

\begin{tabular}{l|c}
\hline & Sayı (n=127) \\
\hline Yatışın olduğu servisler, $\mathbf{n}(\mathbf{\%})$ & $119(93.7)$ \\
Pediatri & $2(1.6)$ \\
Beyin cerrahi & $1(0.8)$ \\
Plastik cerrahi & $1(0.8)$ \\
Kadın doğum & $1(0.8)$ \\
Anestezi & $1(0.8)$ \\
Endokrinoloji & $1(0.8)$ \\
Dermatoloji & $1(0.8)$ \\
Yanık servisi & $70(55.1)$ \\
Hastanede yatış nedeni, $\mathbf{n}$ (\%) & $29(22.8)$ \\
İntihar girişimi & \\
Akut ya da kronik fiziksel hastalık nedeniyle & $20(15.7)$ \\
tedavi amaçlı & $4(3.1)$ \\
Tanı aşamasında olup etiyoloji-ayırıcı tanı & $3(2.4)$ \\
Madde kullanım bozukluğu bulguları & $1(0.8)$ \\
İntihar şüphesi nedeniyle & \\
Diğer (doğum) &
\end{tabular}


Tablo II: Olgulardan konsültasyon istenme nedenleri ve cinsiyetlere göre karşılaştırılması.

\begin{tabular}{|c|c|c|c|c|c|}
\hline & $\begin{array}{l}\text { Toplam } \\
\mathrm{n}=127\end{array}$ & $\begin{array}{c}K ı z \\
n=85\end{array}$ & $\begin{array}{l}\text { Erkek } \\
\mathrm{n}=42\end{array}$ & $\begin{array}{c}\text { Istatistik } \\
\text { Pearson- } X^{2}\end{array}$ & p \\
\hline $\begin{array}{l}\text { Konsültasyon nedeni, n (\%) } \\
\text { İntihar girişimi } \\
\text { Duygusal ya da davranışsal sorunlar } \\
\text { Altta yatan organisitenin yokluğu } \\
\text { Kronik hastalık varlığı } \\
\text { Tedaviye uyumsuzluk ve direnç } \\
\text { Madde kullanımı } \\
\text { Intihar şüphesi } \\
\text { Verisine ulaşlamayan } \\
\text { Diğer§ }\end{array}$ & $\begin{aligned} & 70(55.1) \\
& 20(15.7) \\
& 9(7.1) \\
& 7(5.5) \\
& 7(5.5) \\
& 4(3.1) \\
& 3(2.4) \\
& 1(0.8) \\
& 6(4.7)\end{aligned}$ & $\begin{array}{c}58(68.2) \\
10(11.8) \\
5(5.9) \\
2(2.4) \\
4(4.7) \\
0 \\
1(1.2) \\
1(1.2) \\
4(4.7)\end{array}$ & $\begin{array}{c}12(28.6) \\
10(23.8) \\
4(9.5) \\
5(11.9) \\
3(7.1) \\
4(9.5) \\
2(4.8) \\
0 \\
2(4.8)\end{array}$ & 25.895 & $<.001^{*}$ \\
\hline
\end{tabular}

*: Fisher'in Kesin Testi (Fisher's exact test), ': ajitasyon, hiperaktivite, diş gıcırdatma, içe kapanıklık, kaygı vb. semptomlar, ”: Olgunun konsültasyon istem ve cevap notundan konsültasyon istenme nedeni anlaşılmadı, s: Olgunun kendisinin görüşme yapmak istemesi, aktif yakınma olmayıp özgeçmişinde psikiyatrik öyküsünün olması.

Tablo III: Olgulardan konsültasyon istenme nedenleri ve yaş gruplarına göre karşılaştıılması.

\begin{tabular}{|c|c|c|c|c|c|}
\hline & \multirow{2}{*}{$\begin{array}{c}\text { Toplam } \\
n=127\end{array}$} & \multirow{2}{*}{$\begin{array}{c}\text { Çocuk } \\
n=27\end{array}$} & \multirow{2}{*}{$\begin{array}{l}\text { Ergen } \\
n=100\end{array}$} & \multicolumn{2}{|c|}{ İstatistik } \\
\hline & & & & Pearson- $x^{2}$ & $p$ \\
\hline $\begin{array}{l}\text { Konsültasyon nedeni, n (\%) } \\
\text { İntihar girişimi } \\
\text { Duygusal ya da davranışsal sorunlart } \\
\text { Altta yatan organisitenin yokluğu } \\
\text { Kronik hastalık varlığı } \\
\text { Tedaviye uyumsuzluk ve direnç } \\
\text { Madde kullanımı } \\
\text { İntihar şüphesi } \\
\text { Verisine ulaşılmayan‡ } \\
\text { Diğers }\end{array}$ & $\begin{aligned} & 70(55.1) \\
& 20(15.7) \\
& 9(7.1) \\
& 7(5.5) \\
& 7(5.5) \\
& 4(3.1) \\
& 3(2.4) \\
& 1(0.8) \\
& 6(4.7)\end{aligned}$ & $\begin{array}{c}2(7.4) \\
10(37.0) \\
4(14.8) \\
3(11.1) \\
3(11.1) \\
0 \\
0 \\
1(3.7) \\
4(14.8)\end{array}$ & $\begin{array}{c}68(68.0) \\
10(10.0) \\
5(5.0) \\
4(4.0) \\
4(4.0) \\
4(4.0) \\
3(3.0) \\
0 \\
2(2.0)\end{array}$ & 44.201 & $<.001^{*}$ \\
\hline
\end{tabular}

*: Fisher'in Kesin Testi (Fisher's exact test), t: ajitasyon, hiperaktivite, diş gıcırdatma, içe kapanıklık, kaygı vb. semptomlar, \#: Olgunun konsültasyon istem ve cevap notundan konsültasyon istenme nedeni anlaşılmadı, s: Olgunun kendisinin görüşme yapmak istemesi, aktif yakınma olmayıp özgeçmişinde psikiyatrik öyküsünün olması.

Tablo IV: Konsültasyon sonucunda saptanan psikiyatrik tanılar ve cinsiyetlere göre karşılaştıılması.

\begin{tabular}{|c|c|c|c|c|c|}
\hline & Toplam & Kız & Erkek & İstat & \\
\hline & $n=127$ & $\mathrm{n}=85$ & $n=42$ & Pearson- $\mathrm{x}^{2}$ & p \\
\hline Tanı dağılımı, n (\%) ${ }^{\dagger}$ & & & & & \\
\hline Depresyon & $10(7.9)$ & $7(8.2)$ & $3(7.1)$ & 0.046 & $0.830^{*}$ \\
\hline Anksiyete bozukluğu & $4(3.1)$ & $3(3.5)$ & $1(2.4)$ & 0.122 & $0.727^{\star}$ \\
\hline Madde kullanım bozukluğu & $4(3.1)$ & 0 & $4(9.5)$ & 8.358 & $0.011^{*}$ \\
\hline Uyum bozukluğu & $2(1.6)$ & $2(2.4)$ & 0 & 1.004 & $0.316^{*}$ \\
\hline Bilişsel gelişimde gecikme & $2(1.6)$ & 0 & $2(4.8)$ & 4.112 & $0.108^{*}$ \\
\hline Davranım bozukluğu & $2(1.6)$ & 0 & $2(4.8)$ & 4.112 & $0.108^{*}$ \\
\hline Yeme bozukluğu & $1(0.8)$ & $1(1.2)$ & 0 & 0.480 & $1.000^{*}$ \\
\hline Sınırda bilișsel gelișim & $1(0.8)$ & $1(1.2)$ & 0 & 0.480 & $1.000^{*}$ \\
\hline DEHB & $1(0.8)$ & 0 & $1(2.4)$ & 2.040 & $0.331^{*}$ \\
\hline Otizm & $1(0.8)$ & 0 & $1(2.4)$ & 2.040 & $0.331^{*}$ \\
\hline
\end{tabular}

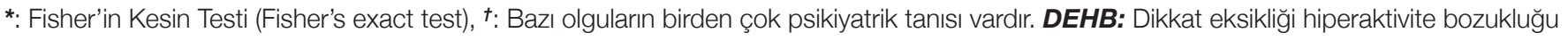

danışıma oranı ergen yaş grubunda anlamlı olarak yüksek bulundu ( $p<0.001$, Fisher' in kesin testi, Tablo III).

Konsültasyon sonucunda saptanan psikiyatrik bozukluk varlığının cinsiyetlere göre karşılaştırımasında, cinsiyetler arasında anlamlı bir fark saptanmadı $(p=0.153$, Fisher' in kesin testi). Psikiyatrik tanılar ayrı ayrı değerlendirilerek analiz edildiğinde madde kullanım bozukluğu tanısı erkeklerde anlamlı olarak yüksek bulundu ( $p=0.011$, Fisher' in kesin testi). Diğer psikiyatrik tanılarda cinsiyetler arasında anlamlı bir fark saptanmadı (Diğer tüm değişkenler için p>0.05, Tablo IV).

Konsültasyon sonucunda saptanan psikiyatrik bozukluk varlığının yaş gruplarına göre karşılaștııımasında, gruplar 
Tablo V: Konsültasyon sonucunda saptanan psikiyatrik tanılar ve yaş gruplarına göre karşılaştıııması.

\begin{tabular}{|c|c|c|c|c|c|}
\hline & \multirow{2}{*}{$\begin{array}{c}\text { Toplam } \\
n=127\end{array}$} & \multirow{2}{*}{$\begin{array}{c}\text { Çocuk } \\
n=27\end{array}$} & \multirow{2}{*}{$\begin{array}{l}\text { Ergen } \\
n=100\end{array}$} & \multicolumn{2}{|c|}{ İstatistik } \\
\hline & & & & Pearson- $x^{2}$ & p \\
\hline \multicolumn{6}{|l|}{ Tanıların dağılımı, n (\%) } \\
\hline Anksiyete bozukluğu & $4(3.1)$ & $1(3.7)$ & $3(3.0)$ & 0.035 & $0.853^{*}$ \\
\hline Madde kullanım bozukluğu & $4(3.1)$ & 0 & $4(4.0)$ & 1.115 & $0.578^{*}$ \\
\hline Uyum bozukluğu & $2(1.6)$ & 0 & $2(2.0)$ & 0.549 & $1.000^{*}$ \\
\hline Yeme bozukluğu & $1(0.8)$ & 0 & $1(1.0)$ & 0.272 & $1.000^{*}$ \\
\hline Sınırda bilişsel gelişim & $1(0.8)$ & $1(3.7)$ & 0 & 3.733 & $0.213^{*}$ \\
\hline DEHB & $1(0.8)$ & 0 & $1(1.0)$ & 0.272 & $1.000^{*}$ \\
\hline Otizm & $1(0.8)$ & $1(3.7)$ & 0 & 3.733 & $0.213^{\star}$ \\
\hline
\end{tabular}

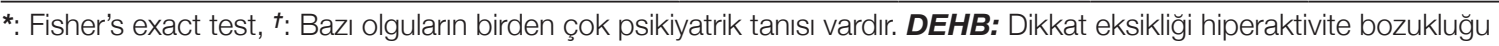

Tablo VI: Psikiyatrik değerlendirme sonuçları ve ilaç kullanımının cinsiyete göre değerlendirilmesi.

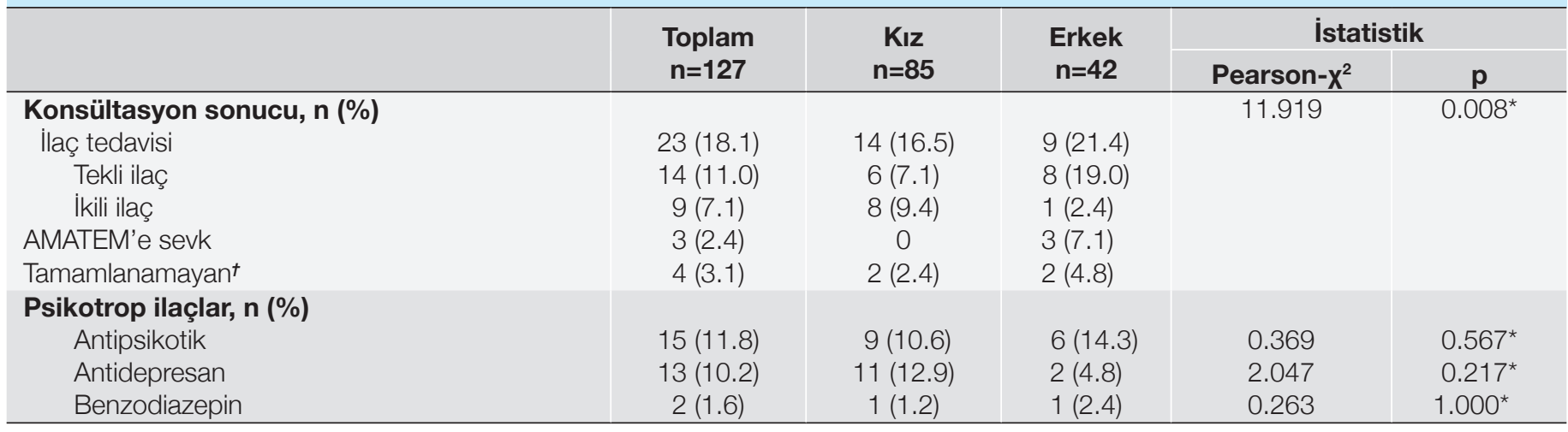

*: Fisher's exact test ${ }^{t}$ : Yatış süresinde olgunun rekonsülte edilmemesi, olgunun görüşme yapmak istememesi. AMATEM: Alkol ve Uyuşturucu Madde Bağımlıları Tedavi ve Araştırma Merkezi.

Tablo VII: Psikiyatrik değerlendirme sonuçları ve ilaç kullanımının yaş gruplarındaki dağılımı.

\begin{tabular}{|c|c|c|c|c|c|}
\hline & \multirow{2}{*}{$\begin{array}{c}\text { Toplam } \\
n=127\end{array}$} & \multirow{2}{*}{$\begin{array}{c}\text { Çocuk } \\
n=27\end{array}$} & \multirow{2}{*}{$\begin{array}{l}\text { Ergen } \\
n=100\end{array}$} & \multicolumn{2}{|c|}{ İstatistik } \\
\hline & & & & Pearson- $x^{2}$ & $\mathbf{p}$ \\
\hline $\begin{array}{l}\text { Konsültasyon sonucu, n (\%) } \\
\text { İlaç tedavisi } \\
\text { Tekli ilaç } \\
\text { İkili ilaç } \\
\text { AMATEM'e sevk } \\
\text { Tamamlanamayant }\end{array}$ & $\begin{array}{c}23(18.1) \\
14(11.0) \\
9(7.1) \\
3(2.4) \\
4(3.1)\end{array}$ & $\begin{array}{c}3(11.1) \\
2(7.4) \\
1(3.7) \\
0 \\
0\end{array}$ & $\begin{array}{c}20(20.0) \\
12(12.0) \\
8(8.0) \\
3(3.0) \\
4(4.0)\end{array}$ & 2.042 & $0.701^{*}$ \\
\hline
\end{tabular}

*: Fisher's exact test, ${ }^{t}$ : Yatış süresinde olgunun rekonsülte edilmemesi, olgunun görüşme yapmak istememesi. AMATEM: Alkol ve Uyuşturucu Madde Bağımlıları Tedavi ve Araştırma Merkezi.

arasında anlamlı bir fark saptanmadı ( $\mathrm{p}=0.494$, Fisher' in kesin testi). Psikiyatrik tanılar ayrı ayrı değerlendirilerek analiz edildiğinde bilişsel gelişimde gecikme tanısının çocuk yaş grubunda anlamlı olarak yüksek olduğu saptandı $(p=0.044$, Fisher' in kesin testi, bakınız Tablo V).

Konsültasyon sonucunda olguların \%18.1'ine $(n=23)$ en az bir psikotrop ilaç önerildiği saptandı. En sık önerilen ilaçların \%11.8 $(n=15)$ ile antipsikotikler ve \%10.2 ( $n=13)$ ile antidepresanlar olduğu görüldü llaç uygulamalarından antipsikotik, antidepresan, benzodiazepin bașlanma oranlarında cinsiyetler arasında anlamlı bir fark saptanmadı $(p=0.567, p=0.217, p=1.000$, Fisher' in kesin testi, Tablo VI).

İlaç uygulamalarından antipsikotik, antidepresan, benzodiazepin bașlanma oranlarında yaș grupları arasında anlamlı bir fark saptanmadı ( $p=0.737, p=0.069, p=0.381$, Fisher' in kesin testi, Tablo VII) 


\section{TARTIŞMA}

Çalışmamızda en fazla çocuk psikiyatri konsültasyonu isteminin pediatri bölümünden yapıldığı saptanmıştır (\%93.7, n=119). Bu oranı Özkan ve ark.(3) \%74.5, Gökçen ve Çelik (13) \%80.7, Emiroğlu ve ark. (12) \%66, Çolpan ve ark.(1) ise \%73 olarak belirtmişlerdir. Bulduğumuz sonucun Türkiye' de yapılmış olan bu çalışmalar ile uyumlu olduğu söylemek mümkündür. Çocuk psikiyatri bölümü ile pediatri bölümünün hizmet verdiği hasta gruplarının benzer ve 18 yaş altı olmasının konsültasyon istenme oranlarını artırdığı düşünülmektedir, ancak pediatri dışı kliniklerden istenilen konsültasyon oranlarının düşük olma intimali de göz önünde bulundurulmalıdır. Bir çalışmada, Türkiye’ de pediatri intisası sırasında bir ay süre ile çocuk psikiyatrisi eğitiminin yer almasının pediatri doktorlarının psikiyatrik semptomları tanıma oranlarını artırabildiğine değinilmiştir (3). Pezzia ve ark.(6) tarafından yapılan bir çalışmada sağlık çalışanlarının aslında psikiyatrik semptomları fark ettikleri ancak psikiyatri konsültasyon servislerini kullanma oranlarının düşük olduğu tespit edilmiş, bu nedenle psikiyatrik semptomların fark edilmesini artıracak stratejiler yerine konsültasyon hizmetlerinin kullanımını artıracak stratejilerin belirlenmesi önerilmiştir. Yapılan çalışmalarda psikiyatri konsültasyonunun az olmasına neden olabilecek bazı durumlar belirtilmiştir. Eğitim sürecindeki eksiklikler, zaman sınırlılı̆̆, yaşamsal sorunlara yönelik hizmetlerin ön plana çıkması nedeniyle psikiyatrik değerlendirmeye öncelik verilmemesi, çocuk psikiyatrisine erişim sorunları, ailelere psikiyatrik yardım gerekliliğini açıklamakta zorlanma gibi sebepler bunlardan bazılarıdır $(1,12,13)$. Chen ve ark. (7) tarafından yapılan derleme çalışmasında bu durumun olası sebepleri sistemsel faktörler, konsülte eden kişiye yönelik faktörler ve hastaya yönelik faktörler olmak üzere üç kategoride belirtilmiştir. Yapılan çalışmalarda ruh sağlığı hizmetlerine erişimde engeller olabileceğine ve gereksinim duyulduğundan çok daha az çocuk psikiyatri konsültasyonu istenebildiğine dikkat çekilmiştir $(12,13)$. Tüm bu durumlar KLP bölümünün önemini ve bu yöndeki hizmetlerin geliştirilmesi gerektiğini göstermektedir.

Çalışmamızda olguların \%78.7'sinin ergen yaş grubunda (13-17 yaş) olduğu ve tüm olguların \%66.9'unun kız olduğu saptanmıştır. Kız olgu sayısının ve ergen yaş grubunun üstünlüğü Türkiye' de yapılan diğer çalışma sonuçları ile benzerdir $(1,3,12,13,14)$. Çalışmamızda konsültasyon istenme nedenlerinin en başında \%55.1 ile $(n=70)$ intihar girişiminin değerlendirilmesi istemi bulunmaktadır. Yapılan bir derleme çalışmasında en sık çocuk psikiyatri konsültasyonunun intihar riskinin değerlendirilmesi nedeni ile istenildiği belirtilmiştir (10). Özkan ve ark. (3) ile Göker ve ark.(14) çalışmalarında en sık konsültasyon nedenini intihar girişimi olarak saptamışlardır. Bu sonuçlar çalışmamızın sonucunu destekler niteliktedir. Emiroğlu ve ark. (12) tarafından yapılan çalışmada ise en sık konsültasyon nedeni depresif belirtiler olarak bulunmuştur . Yatan hastalarda yapılan konsültasyon çalışmaları incelendiğinde çalışmanın yapıldığı dönem, çalışmanın yürütüldüğü hastanenin türü gibi değişkenlerin sonuçları etkileyebileceği bildirilmiştir. Ayrıca konsültasyon istenme nedeni değerlendirilirken bu veriyi gruplandırmanın kolay olmadığına da değinilmiştir (4). Konu ile ilgili yapılan çalışmalarda bulunan farklı sonuçların bu durumdan kaynaklandığı düşünülmektedir. İntihar konusunda yapılan çalışmalar incelendiğinde intihar girişiminin kızlarda daha fazla olduğu görülmektedir $(15,16)$. İntihar girişiminin değerlendirilmesi istemi, çalışmamızdaki en sık konsültasyon nedeni olarak tespit edilmiştir. Çalışmamızdaki olguların büyük çoğunluğunun kız olmasının bu sonuç ile ilişkili olabileceği düşünülmüştür.

Enyaygınistenen çocukpsikiyatrikonsültasyon sebeplerindenbiri de kronik hastalıklara uyum süreci ile ilgilidir (10). Çalışmamızdaki olguların \%5.5' i ( $n=7)$ kronik fiziksel bir hastalığının olması nedeniyle çocuk psikiyatrisine yönlendirilmiştir. Fiziksel hastalığı olan bireylerdeki olası psikiyatrik sorunların saptanması için psikiyatri konsültasyonun istenmesi, zamanla rutin muayenenin bir parçası haline gelmiş ve yaygınlaşmaya başlamıştır (10). Konsültasyon-liyezon hizmetlerine yönelik farkındalığın zaman içinde artmış olduğu görülmektedir.

Otizm Spektrum Bozukluğu (OSB) tanılı çocuklarda fiziksel hastalık sıklığı genel popülasyona göre daha yüksektir (10). Çalışmamızda sadece tek bir olguda OSB tanısı bulunmaktadır. Bunun nedeninin çalışmamızın sadece yatan hasta grubuyla yapılmış olmasından kaynaklandığı düşünülmektedir.

Altta yatan organik bir bozukluğun saptanamaması nedeniyle istenilen konsültasyonların oranı çalışmamızda \%7.1 ( $n=9)$ olarak saptanmıştır. Amerikan Çocuk ve Genç Psikiyatri Birliği (AACAP)' nin somatik semptom ve ilişkili bozukluklar ayırıcı tanısı olan olgularda hastanede kalma süresinde çocuk psikiyatrisinin sürece erken dahil edilmesini önerdiği bildirilmiştir (10). Tøt-Strate ve ark. tarafından ise fonksiyonel somatik semptomları olan çocuklarda ciddi semptomlar olması ya da tanı koyulamaması durumunda çocuk psikiyatri konsültasyonu önerilmiştir (8). Yetişkin psikiyatri kliniği tarafından yürütülen bir çalışmada fiziksel semptomları olan hastalarda organik nedenler ekarte edilmeden psikiyatrik tanıların düşünülmesinin esas hastalıkların tanısını geciktirebilme riskinden bahsedilmiştir (4). Pezzia ve ark. (6) tarafından yapılan çalışmada, psikiyatrik öyküsü olan her hastanın otomatik olarak psikiyatriye konsülte edilmesinin hem maliyet hem yararlılık açısından uygun olmayabileceğine değinilmiştir. Tüm bu çıkarımlar dikkate alındığında diğer tıbbi birimlerdeki hekimlerin psikiyatrik değerlendirmeyi sürece dahil edecekleri zamanı olgu bazında karar vermesi daha uygun görünmektedir.

Çalışmamızda sadece tek bir olgudan neden psikiyatri konsültasyonu istendiği anlaşılamamıştır. Türkiye' deki çocuk ya da yetişkin psikiyatrisi kliniği tarafından yürütülmüş bazı çalışmalarda psikiyatrik bir neden gösterilmeksizin çeşitli oranlarda konsültasyon istenebildiği gösterilmiştir $(1,4,5)$. Konsültasyon sürecinin her aşamasında klinikler arasındaki iş birliğinin ve iletişimin iyi olmasının, bir hastanın 
en uygun koşullarda değerlendirilmesine katkıda bulunacağı düşünülmektedir.

Çalışmamızda değerlendirilen kesitte olguların \%19.7' sinde $(\mathrm{n}=25)$ DSM-5 tanı ölçütlerini karşılayan en az bir psikiyatrik bozukluk saptanmıştır. Diğer çalışmalar incelendiğinde en az bir psikiyatrik tanısı olan olguların sayısı Özkan ve ark.(3) tarafından \%83.6, Emiroğlu ve ark. (12) tarafından \%81.7, Gökçen ve Çelik (13) tarafindan ise \%86 olarak belirtilmiştir. Bizim sonucumuzun Türkiye' de yapılan benzer çalışmalarda bulunan sonuçlara göre oldukça düşük olduğu söylenebilir. Bunun nedeninin çalışmamızdaki olguların yatış süresinin ya da yatış süresinde yapılan psikiyatrik değerlendirme sayısının psikiyatrik tanılama süreci için yeterli olmamasından kaynaklandığı düşünülmektedir. Yetişkin psikiyatri kliniği tarafından yürütülen bir çalışmada ise herhangi bir ruhsal hastalığı bulunmayan kişilerden psikiyatri konsültasyonlarının fazla istendiği sonucu bulunmuş ve bu durum psikiyatrik hastalıkların tanınmasında yetersizlikle ilişkilendirilmiştir (4). Hekimlerin yasal sorunlarla karşılaşmamak için de gerekenden daha fazla psikiyatri konsültasyonu isteyebilecekleri düşünülmektedir. Tüm bu faktörlerin sonuçları etkileyebileceği göz önünde bulundurulmalıdır.

Çalıșmamızda konsültasyon sonucunda en sık saptanan psikiyatriktanının depresyon olduğu bulunmuştur. Daha önceden yapıımış olan çalışmalarda benzer şekilde depresyon tanısının en sık bulunduğu çalışmalar olmakla birlikte; uyum bozukluğu, anksiyete bozukluğu gibi tanıların da en sık gösterildiği çalışmalar bulunmaktadır (3,12-14,17). Konsültasyon sonucunda saptanan psikiyatrik tanılar farklı yayınlarda farklı sıralamalarda bildirilmiştir (14). Öncesinde belirtildiği gibi araştırmaların yapıldığı dönem, hastane türü gibi değişkenler bu sonuçları etkileyebilmektedir (4). Göker ve ark. (14) tarafından yapılan çalışmada ayrıca, intihar girişimi dışında yatan çocuk hastalardan istenen konsültasyon oranlarının yurtdışında bildirilen oranların oldukça gerisinde kaldığı vurgulanmıştır.

Çalışmamızda madde kullanım bozukluğu tanısının erkeklerde anlamlı olarak daha yüksek olduğu bulunmuş ancak diğer psikiyatrik tanılarda cinsiyetler arasında anlamlı bir fark saptanmamıştır. Emiroğlu ve ark. (12) tarafindan yapılan çalışmada da konsültasyon sonucunda saptanan tanıların cinsiyete göre farklıașmadığı belirtmiş olup çalıșmamızın sonucunu destekler niteliktedir. Ayrıca çalışmamızın sonucu madde kullanım bozukluğunun erkek cinsiyette daha fazla görüldüğünü bildiren çalışma sonuçları ile de uyumludur (18).

Çalışmamızda olguların \%18.1'ine en az bir psikotrop ilaç önerildiği saptanmış olup Türkiye' de yapılan diğer çalışmalarda bu oranlar sırası ile \%38.2, \%38.5, \%70.2, \%36.6 bulunmuştur $(3,12,13,14)$. Bizim sonucumuz bahsedilen çalışmalarda bulunan sonuçlara göre daha düşüktür. Bu sonucun çalışmamızda saptanan psikiyatrik tanı oranlarının düşüklüğü ile ilişkili olduğu düşünülmektedir. Çalışmamızda önerilen psikotrop ilaçlar \%11.8 ( $n=15)$ ile antipsikotikler, \%10.2 ( $n=13)$ ile antidepresanlar, \%1.6 $(n=2)$ ile benzodiazepinler olarak bulunmuştur. Özkan ve ark. (3) tarafindan yapılan çalışmada bu oranlar sırası ile \%10.9, \%21.8, \%5.5 olarak belirtilmiştir. Psikotrop ilaçların molekül bazı sınıflandırıldı̆̆ı çalışmalar da bulunmaktadır $(12,13,14)$. Çalsşmamızda antipsikotik, antidepresan, benzodiazepin başlanma oranlarında cinsiyetler arasında anlamlı farkllık bulunmamıştır. Gökçen ve Çelik (13) tarafından yapılan çalışmada erkekler ve kılarda psikotrop ilaç kullanım oranları arasında fark bulunmadığı, Göker ve ark. (14) tarafından yapılan çalışmada cinsiyetlere göre dağılımın psikotrop önerisini etkilemediği belirtilmiştir. Bu sonuçlar çalışmamızla uyumlu görünmektedir; ancak Emiroğlu ve ark. (12) tarafindan yapılan çalışmada ise erkeklerde psikotrop ilaç kullanım oranııın kızlardan anlamlı düzeyde yüksek olduğu bulunmuştur.

Pediatrik deliryum ciddi hastalığı olanlarda \%20-\%25 oranında görülebilmektedir (10). Çallşmamızın konsültasyon sonuçları değerlendirildiğinde deliryum tanısı konmuş olgu saptanmamıştır. Çalışmanın kapsadığı dönemde hastanemizin kliniklerinde ağır hastanın yatmamış olması, deliryum için tanı farkındalığının az olması ya da olgunun fiziksel hastalığının tedavisini yürüten klinik doktorunun psikiyatriye danışmadan deliryum tedavisini düzenlemiş olması gibi faktörler bu durum ile ilişkili olabilir. Le ve ark. (19) tarafindan yapılan bir çalışmada psikiyatri dışı pediatrik yatan hasta grubunda antipsikotik ilaç başlanmasının en sık sebebinin deliryum olduğu saptanmıştır. Aynı çalışmada ayrıca, psikiyatri dışı bölümlerde hastaya antipsikotik ilaç tedavisi planlandığında, tedavi sürecine psikiyatri biriminin dahil edilmesi durumunda ilaç yan etkisi izleminin arttığı ve bu konuya daha fazla dikkat edildiği vurgulanmıştır. Bu nedenle psikiyatri dışı branşlarda herhangi bir sebeple antipsikotik ilaç tedavisi planlanan olgularda psikiyatrinin sürece dahil edilmesinin gerekli olduğu söylenebilir.

Çalışmamızın geriye dönük kesitsel bir çalışma olması, sadece yatan hastaların dahil edilip ayaktan konsülte edilen hastaların dahil edilmemiş olması kısıtlılık olarak değerlendirilebilir.

Çalısmamızda Konsültasyon Liyezon Psikiyatrisi biriminin önemine dikkat çekilmiştir. Konsültasyon-Liyezon alanındaki farkındalı̆ı̆ı artması olumlu yönde bir gelişme olarak değerlendirilmiş ancak bu alandaki hizmetlerin daha fazla geliştirilmesi gerektiği düşünülmüştür. Ülkemizde yapılan çalışmalarda bulunan farklı sonuçlar değerlendirildiğinde konsültasyon-liyezon alanında ortak bir dil ve algoritma oluşturulmasının önemli olduğu düşünülmüștür.

\section{KAYNAKLAR}

1. Çolpan M, Eray Ș, Vural P. Uludağ Üniversitesi Hastanesinde Son Bir Yılda İstenen Çocuk ve Ergen Psikiyatrisi Konsültasyonlarının Değerlendirilmesi. Güncel Pediatri 2013;11:101-6.

2. Özkan, S. Konsültasyon Liyezon Psikiyatrisi; Kavramlar, Kurumsallaşma, Uygulama. Turkiye Klinikleri J Int Med Sci 2006;2:1-13. 
3. Özkan ÖG, Sapmaz ȘY, Kandemir H. Pediatri Kliniğinde Yatarak Tedavi Gören Hastalarda, Çocuk Psikiyatrisi Konsültasyonlarının Değerlendirilmesi. Klinik Psikiyatri Dergisi 2017; 20:287-93.

4. Ertek IE, Öztürk HM. Bir eğitim-araştırma hastanesinde istenen psikiyatri konsültasyonlarının değerlendirilmesi ve psikiyatrik hastalıkların doğru tanınma oranları. Klinik Psikiyatri Dergisi 2019; 22:338-46.

5. Kılıç EK, Çınar RK, Sönmez MB, Görgülü Y. Bir Üniversite Hastanesinde Yatan Hastalardan İstenen Psikiyatrik Konsültasyonlarının Değerlendirilmesi. Klinik Psikiyatri Dergisi 2016;19:194-201.

6. Pezzia C, Pugh JA, Lanham HJ, Leykum LK. Psychiatric consultation requests by inpatient medical teams: an observational study. BMC Health Serv Res 2018;18:336.

7. Chen KY, Evans R, Larkins S. Why are hospital doctors not referring to Consultation-Liaison Psychiatry? - a systemic review. BMC Psychiatry 2016;16:390.

8. Tøt-Strate S, Dehlholm-Lambertsen G, Lassen K, Rask CU. Clinical features of functional somatic symptoms in children and referral patterns to child and adolescent mental health services. Acta Paediatr 2016;105:514-21.

9. Çöp E, Dinç G , Kültür S . Kronik Hastalığı Olan Çocukların Annelerinde Baș Etme Becerilerinin Psikiyatrik Belirtiler ile İlişkisi: Bir Ön Çalışma. Türkiye Çocuk Hast Derg 2016;10:170-6.

10. Becker JE, Smith JR, Hazen EP. Pediatric Consultation-Liaison Psychiatry: An Update and Review. Psychosomatics 2020;61:46780.
11. Leigh H, Streltzer J. (Güleç H, Yalçın M, Ünübol H, Karșıdağ Ç. Çev ed). Konsültasyon -Liyezon (Danışma-Dayanışma) Psikiyatrisi. Nobel Tıp Kitabevleri. Ankara 2017.

12. Emiroğlu N, Aras Ş, Yalın Ş, Doğan Ö, Akay A. Yatan hastalar için istenen çocuk ve ergen psikiyatrisi konsültasyonlarının değerlendirilmesi. Anadolu Psikiyatri Dergisi 2009;10:217-25.

13. Gökçen C, Çelik Y. Bir Eğitim Hastanesi'nde Yatan Hastalar İçin İstenen Çocuk ve Ergen Psikiyatri Konsültasyonlarının Değerlendirilmesi. Sakarya Tıp Dergisi 2011;1:140-4.

14. Göker Z, Güney E, Dinç G, Üneri Ö. Bir eğitim ve araștırma hastanesinde yatarak tedavi gören çocuk ve ergenler için istenen psikiyatri konsültasyonlarının değerlendirilmesi. Türkiye Çocuk Hast Derg 2014;1:17-24.

15. Șevik AE, Özcan H, Uysal E. İntihar Girișimlerinin İncelenmesi: Risk Faktörleri ve Takip. Klinik Psikiyatri Dergisi 2012;15:218-25.

16. Aktepe E, Kandil S, Göker Z, Sarp K, Topbaş M, Özkorumak E. Intihar Girişiminde Bulunan Çocuk ve Ergenlerde Sosyodemografik ve Psikiyatrik Özelliklerin Değerlendirilmesi. TAF Preventive Medicine Bulletin 2006;6:444-54.

17. Carter BD, Kronenberger WG, Baker J, Grimes LM, Crabtree VM, Smith C, McGraw K. Inpatient pediatric consultation-liaison: a case-controlled study. J Pediatr Psychol 2003;28:423-32.

18. Ögel K. Madde Kullanım Bozuklukları Epidemiyolojisi. Turkiye Klinikleri J Int Med Sci 2005; 1:61-4.

19. Le L, Bostwick JR, Andreasen A, Malas N. Neuroleptic Prescribing and Monitoring Practices in Pediatric Inpatient Medical and Psychiatric Settings. Hosp Pediatr 2018;8:410-8. 